\title{
Natural resistance of wood from three forest species exposed to Pycnoporus sanguineus xylophagous fungus
}

\author{
Alisson Rodrigo Souza Reis ${ }^{1 *}$, Andrielly Gomes Loch $^{1}$, Simone Maria da Costa Oliveira Moreira ${ }^{1}$, Matheus da \\ Costa Gondim ${ }^{2}$, Marcio Rogério da Silva ${ }^{1}$, Patrícia Soares Bilhalva dos Santos ${ }^{1}$
}

${ }^{1}$ Federal University of Pará, Coronel José Porfírio St.- São Sebastião, Altamira - PA, 68376-040

2 Federal Rural University of Amazônia, Presidente Tancredo Neves Avenue, No 2501, Terra Firme, Belém-PA, 66077-830

*Author for correspondence: alissonreis@ufpa.br

Received: December 2019/ Accepted: December 2019/ Published: December 2019

\begin{abstract}
Wood is subject to degradation by biological agents. Therefore, studies are necessary to ensure its appropriate use, avoid economic losses. The objective of this study was to assess the natural resistance of Spanish cedar (Cedrela odorata), yellow ipe (Handroanthus serratifolius) and tauari (Couratari sp.) woods exposed under laboratory conditions to Pycnoporus sanguineus fungus, which causes white rot. The decay test was conducted according to the method defined in the American Society for Testing and Materials, and the intensity of biodeterioration was determined by mass loss of the three test woods and one control wood, pumpwood (Cecropia sp.), which has low natural resistance. Analy sis of variance and Tukey's test $(p<0.05)$ were used in the analy sis of results. The wood species were classified as highly resistant and resistant to P. sanguineus. Yellow ipe was the most resistant species to fungus attack, whereas tauari was the most susceptible.
\end{abstract}

Keywords: biodeterioration, natural durability, mass loss.

\section{Introduction}

The tropical Amazonian woods are highly sought after for their technological properties, among them the natural durability is the most important, but because they are highly durable wood it is not known how long these woods, mainly exposed to fungi, can remain intact.

The natural durability of wood is one of the main factors that determine its use (Romanini et al., 2014). Despite the importance of characterizing the natural resistance of wood, in addition to the description of other technological properties, few studies have focused on wood from the Amazonian species (Pilocelli et al., 2015).

Because of the diversity of forest species and existing empirical knowledge, these woods are thought to last for years and even centuries, an idea that often lacks the support of any technical-scientific study to confirm it. Moreover, the natural durability of these woods varies as they are exposed to the action of wood-degrading agents.

Studies that address the adequate length of time to conduct the accelerated laboratory test of decay are currently conducted according to the American Society for Testing and Materials (ASTM), which was developed for woods from temperate-climate forests. It is important to gain insight into the natural resistance of tropical woods and the behavior of fungi in the decay process by laboratory testing, with the aim of establishing standards, for tropical woods, as there are no specific norms and standards (Stangerlin et al., 2013).

Wood degradation by insects or microorganisms is a fundamental step in nutrient recycling within an ecosystem. However, biological agents cause great damage that affect wood structures (Motta et al., 2013). Being the decay fungi are the main wood-degrading agents (Batista et al., 2013), because they develop rapidly and in different environments, depending on the occurrence of favorable conditions such as humidity, temperature, $\mathrm{pH}$, and oxy gen availability. Physical and chemical agents act in combination with fungi that decompose wood to use its components as a feeding source, thereby accelerating the decay process (Moreschi, 2013).

Decay fungi produce the most harmful effects on wood, in particular those that cause white rot, by indistinctly decomposing lignin, cellulose, and hemicellulose, which gives a lighter color to the material (Modes et al., 2012). Pycnoporus sanguineus (L.) Murrill, commonly known as urupê or orelha-de-pau, causes white rot and is widely distributed in nature; it is found both in regions with milder climates and in tropical forests, such as the Amazon rainforest (Esposito et al., 1993, cited by Modes et al., 2012). The degree of resistance to biological agents significantly varies between species, which may be attributed to the presence of secondary components in the wood, such as tannins, extractives, and other complex phenolic substances, that are toxic to those degrading agents (Oliveira et al., 2005).

Thus, to establish criteria for wood use, it is essential to obtain data on natural durability (Alves et al., 2006). Knowledge regarding processes involved in wood decay generates potential information to assess these species and to better understand and harness the properties of each wood. The result is the containment of costs and waste that would occur with the replacement of deteriorated woods, reducing the impact on forests (Marcondes et al., 2013).

Therefore, more studies are needed to evaluate the Amazonian species with regard to their wood durability and wood degradation (Modes et al., 2012). In this context, The objective of this study was to assess the natural resistance of Spanish cedar (Cedrela odorata), yellow ipe (Handroanthus serratifolius) and tauari (Couratari sp.) woods exposed under laboratory conditions to Pycnoporus sanguineus fungus, which causes white rot.

\section{Material and methods Local and origin of wood species}

The study was conducted in the Laboratory of Wood Technology of the School of Forest Engineering and in the Laboratory of Plant Pathology of the School of Agricultural Engineering of the Federal University of Pará (UFPA), Campus of Altamira, State of Pará, Brazil. The experiment was performed according to procedures described in the American Society for Testing and Materials - ASTM D 2017 (2005), with adaptations, as the number of samples and the number of weeks due to the quantity of material, besides the use of lumber

The tested woods sawn were Spanish cedar (Cedrela odorata L.), yellow ipe (Handroanthus serratifolius [Vahl] S.O. Grose), and tauari (Couratari sp.), which were purchased in a sawmill in the municipality of Anapu, State of Pará, Brazil.

\section{Preparation of test specimens and decay test}


Test specimens measuring $25 \times 25 \times 0.90 \mathrm{~mm}$ were prepared from heartwood, using the middle part of the heartwood. Twelve test specimens were selected for each species of wood, due to the availability of infrastructure. Specimens without defects were sanded and selected. They were subsequently kept in an oven at $50 \pm 1{ }^{\circ} \mathrm{C}$ for $24 \mathrm{~h}$ and sterilized before inoculation by placing them in an autoclave at $121^{\circ} \mathrm{C}$ for $30 \mathrm{~min}$. In addition, 12 samples of heartwood from pumpwood (Cecropia sp.) were prepared to be used as controls.

Pycnoporus sanguineus (L.: Fr.) Murrill that causes white rot was used in the test. It was grown in a culture medium containing malt extract and distilled water. The fungi inocula of approximately $1 \mathrm{~cm}^{2}$ were added to the liquid culture medium and kept in an incubator at $27 \pm 1{ }^{\circ} \mathrm{C}$ and relative humidity of $70 \pm 4 \%$ for two weeks, until the mycelium covered the culture medium surface.

Distilled water and $90 \mathrm{~g}$ of soil [(Red Latosol (Oxisol)] free of microorganisms were added to the glass vials, with a capacity of $250 \mathrm{ml}$. Which was subsequently autoclaved at $120^{\circ} \mathrm{C}$ for $20 \mathrm{~min}$. In each vial, pumpwood (Cecropia sp.) support plates measuring $35 \times 29 \times 3 \mathrm{~mm}$ were placed over the soil for the initial development of white rot fungus. The vials were autoclaved at $121^{\circ} \mathrm{C}$ for $30 \mathrm{~min}$.

Subsequently, the vials were inoculated and stored in the incubator for three weeks at $27 \pm 1^{\circ} \mathrm{C}$ until the mycelium completely covered the support plate. After the support plates were colonized, test specimens were stored in the vials for 12 weeks. At the end of the fungus colonization period, specimens were removed from the vials and the mycelium covering them was removed with a brush. Then, they were maintained in an oven at $50 \pm 1^{\circ} \mathrm{C}$ for $24 \mathrm{~h}$ and subsequently weighed to determine mass loss.

The attack susceptibility index (DSI) was applied to the samples, according to the methodology of Curling and Murphy (2002), using the following equation:

$$
D S I=\frac{\% \text { mass loss of sample }}{\% \text { mass loss of reference timber }} \times 100
$$

\section{Mass loss of test specimens and statistical analyses}

The species were classified with regard to resistance to fungus attack based on the mean mass loss according to the classes of resistance established by the ASTM D 2017 (2005) (Table 1)

Table 1. Resistance classes of wood subjected to xy lophagous fungus in relation to mass loss.

\begin{tabular}{cc}
\hline Mass loss (\%) & Classes of Resistance \\
\hline $0-10$ & Highly resistant (HR) \\
\hline $11-24$ & Resistant (R) \\
\hline $25-44$ & Moderate resistance (MR) \\
\hline$>45$ & Non-resistant (NR) \\
\hline
\end{tabular}

Statistical analysis of data was conducted using analysis of variance (ANOVA) in a completely randomized experiment and Tukey's test $(\mathrm{p}<0.05)$ to determine statistically significant differences between means, when $\mathrm{F}$ test was significant $(p<0.05)$. All tests were applied after verification of data normality through the Shapiro-Wilk test. Data were analyzed using ASSISTAT 7.7 software (Silva e Azevedo, 2016)

\section{Results and discussion}

Results presented in Table 2 show that mass loss for the species exposed to white rot fungus (Pycnoporus sanguineus) attack did not statistically differ between the tauari (Couratari sp.) and Spanish cedar (Cedrela odorata) woods. The lowest percentage of mass loss was observed for the yellow ipe (Handroanthus serratifolius) wood, which was, therefore, the most resistant to the causal agent of white rot. Figure 01 shows test phases.

The species exhibited values of mass loss $<11.12 \%$. Alves et al. (2006) obtained values of mass loss between $0.05 \%$ and $3.21 \%$ for wood from species of the Amazon rainforest exposed to accelerated decay by $P$. sanguineus.
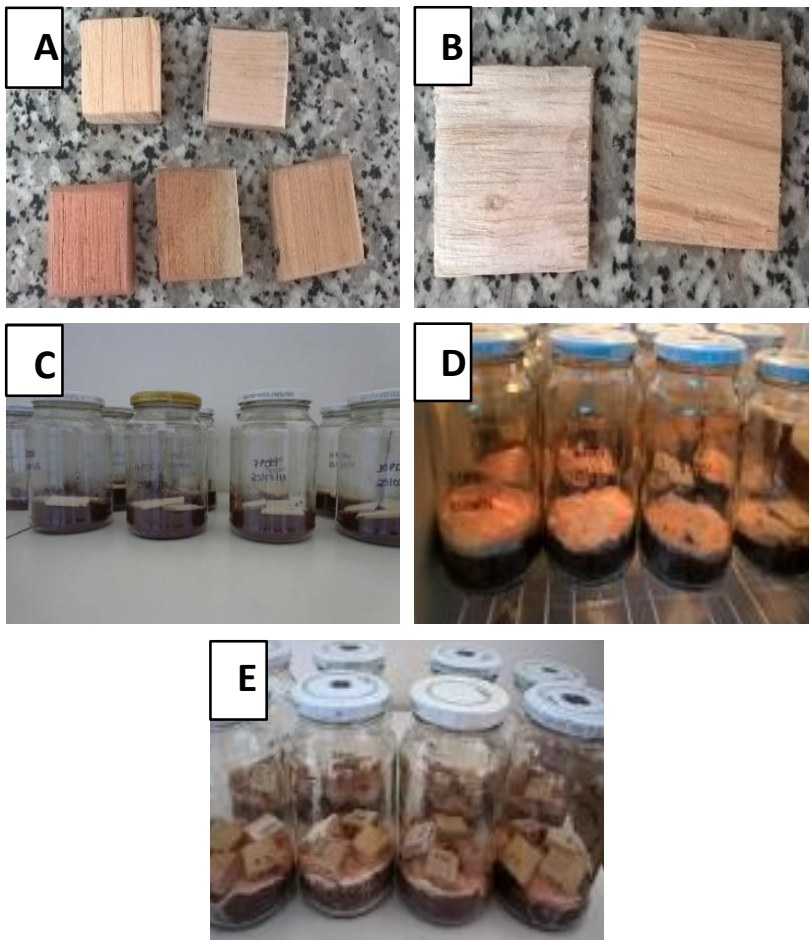

Figure 1: A - Samples before being tested; B - Support samples for fungal colonization; C-D - Samples during the test; E - Samples after test completion

The control species, pumpwood (Cecropia sp.), was intensely attacked by $P$. sanguineus). It lost $>50 \%$ of its mass over a period of 12 weeks and was, therefore, classified as non-resistant according to the indication of the ASTM D 2017 (2005), which confirmed the vigor of the fungus. Carvalho et al. (2015) obtained a mean loss of $52.31 \%$ for the control species, which confirms the test validity.

Results obtained showed that mass loss due to the white rot fungus was low and the species were, therefore, classified as highly resistant and resistant (Table 2). The tauari (Couratari sp.) wood was the most susceptible to attack by the fungus and was classified as resistant, which demonstrates that the intensity of attack by fungi is species-related and that a species' resistance depends on the distinct needs of fungus relative to the composition of each forest species (Carvalho et al., 2015)

In their study, Okino et al. (2015) showed that tauari (Couratari stellata) wood was the least susceptible to attack by the white rot fungi Trametes versicolor and Ganoderma applanatum, with the lowest mass loss (18.46 and 16.74\%), respectively, and classified this wood as resistant. The classes of resistance in which the species Couratari oblongifolia and Couratari guianensis were included varied from moderately 
resistant to resistant when exposed to the fungi; however, they did not differ $(p>0.05)$. Therefore, that result is in line with that obtained in the present study, which classified tauari wood as resistant.

Table 2. Mean values with standard deviation of mass loss and resistance classification of species submitted to $P$. sanguineus.

\begin{tabular}{lccc}
\hline \multirow{2}{*}{$\begin{array}{c}\text { Wood } \\
\text { species }\end{array}$} & $\begin{array}{c}\text { Name } \\
\text { Scientifics }\end{array}$ & \multicolumn{2}{c}{ Pycnoporus sanguineus } \\
\cline { 3 - 4 } & & $\begin{array}{c}\text { Mass loss } \\
(\%)\end{array}$ & $\begin{array}{c}\text { Class of } \\
\text { resistance }\end{array}$ \\
\hline Yellow ipe & $\begin{array}{c}\text { Handroanthus } \\
\text { serratifolius } \text { (Vahl) } \\
\text { S. O. Grose }\end{array}$ & $\begin{array}{c}6.76 \pm 2.3 \\
\mathrm{c}\end{array}$ & AR \\
\hline Tauari & Couratari sp & $\begin{array}{c}11.12 \pm \\
1.9 \mathrm{~b}\end{array}$ & $\mathrm{R}$ \\
\hline Spanish cedar & Cedrela odorata $\mathrm{L}$. & $\begin{array}{c}8.70 \pm 3.0 \\
\mathrm{c}\end{array}$ & $\mathrm{AR}$ \\
\hline Pumpwood & Cecropia sp & $\begin{array}{c}55.84 \pm \\
4.3 \mathrm{a}\end{array}$ & $\mathrm{NR}$ \\
\hline
\end{tabular}

Means followed by the same letter do not differ (Tukey; $p$ > 0.05); Highly resistant (HR); Resistant (R); Non-resistant (NR), as ASTM D 2017 (2005).

According to the findings of Nahuz et al. (2013), tauari wood exhibited low resistance to attack by xylophagous organisms under laboratory conditions, and tauari wood was deemed non-durable in a field test with wood in contact with the soil, with a service life of less than two y ears. In this sense, the high humidity that is characteristic of the Amazon rainforest is a factor that influences the increased attack by wood-decay fungi (Batista, 2013).

In a study conducted with a species of jequitibá (Cariniana micrantha), of the same family as the tauari species, Stangerlin et al. (2013) classified this wood as moderately resistant to attack by white rot fungus because it exhibited a mass loss of $42.48 \%$ over the 12 -week laboratory experiment.

The yellow ipe (Handroanthus serratifolius) wood exhibited a lower loss of mass and was categorized as highly resistant. This feature may be explained by the species' intrinsic ability to resist the action of degrading agents, whether they are biological, physical, or chemical, as well as by the concentration of extractives present in the wood that are toxic to the fungi (Paes, 2002). According to the Institute of Technological Research of the State of São Paulo - IPT (2016), y ellow ipe wood has been shown to be highly resistant to attack by xy lophagous organisms in laboratory tests.

To the natural resistance of wood species to xy lophagous fungi Paes et al. (2007) observed that denser woods, generally, were the most resistant to decay. This fact confirms the behavior of the yellow ipe species relative to the other species, i.e., its higher resistance to the fungus. However, the same authors reported that, within the same species, natural resistance, chemical composition, and cellular structure are not always associated with wood density.

The Spanish cedar (Cedrela odorata) wood exhibited a mass loss of approximately $8 \%$, i.e., was highly resistant to the fungus. In an experiment conducted by the Brazilian Institute of Technological Research - IPT (2016), this wood species exhibited moderate durability and its service life was shown to be less than 12 years in ground contact.

To the Australian cedar (Toona ciliata), Almeida et al. (2012) classified it as moderately resistant after a mass loss of $27.79 \%$ due to exposure to the white rot fungus Trametes versicolor. To the natural resistance of African mahogany woods (Khaya senegalensis and Khaya ivorensis), which belong to the same family as cedar, França (2014) to the mean loss of mass as a result of exposure to the white rot fungus
(Trametes versicolor) was $24.3 \%$ and $28.2 \%$, respectively. The woods were classified as moderately resistant. Cedar wood was shown to be more resistant to fungus attack than the mahogany species; the differences in mass loss may be associated with the characteristics of the wood species because resistance may vary between species of the same family and within the same species.

Because the ASTM D 2017 (2005) is an accelerated version of the process of wood decay in the field, it requires a time of exposure to fungi of at least 12 weeks. The study analyzed woods in the minimum time required to determine the percentage of mass loss to determine its relevance, considering that the Amazonian species may be more or less resistant to degradation. Thus, knowledge about the behavior of biological properties in the initial stages of decay is important for a more effective control of potential damages due to wood-degrading fungi (Stangerlin et al., 2013).

According to Stangerlin et al. (2013), the assessment of the Amazonian species showed that the mean loss of mass did not stabilize over the 12 weeks of the decay test. Therefore, they state that the period of attack by decay fungi set out in the ASTM D 2017 was insufficient for the assessment of the woods in question and suggested that parameters in the standard be reviewed for tropical woods.

It was observed that all species studied presented the index below 100 for the tested fungus, indicating that the species have little susceptibility to the attack, when compared to the reference wood. The values found for the studied species are lower than those found by Carvalho et al (2015) studying forest species such as Eucalyptus robusta, E. tereticornis and Hoenia dulcis, showing the resistance of tropical Amazonian wood.

Tabela: Values of index of susceptibility of to attack \% (DSI)

\begin{tabular}{ccc}
\hline $\begin{array}{c}\text { Wood } \\
\text { species }\end{array}$ & Name Scientifics & DSI \\
\hline Yellow ipe & Handroanthus serratifolius (Vahl) & $12.10 \pm$ \\
& S. O. Grose & $0.75 \mathrm{a}$ \\
Tauari & Couratari sp & $19.91 \pm 0.69$ \\
& & $\mathrm{~b}$ \\
Spanish & Cedrela odorata $\mathrm{L}$ & $15.58 \pm 1.20$ \\
cedar & & $\mathrm{b}$ \\
\hline
\end{tabular}

\section{Conclusion}

In conclusion, the wood species were classified as highly resistant and resistant to the white rot fungus (Pycnoporus sanguineus) in this study, with yellow ipe being the most resistant wood and tauari being the most susceptible species. Further studies are required to assess the natural resistance of species over longer periods to determine the viability of attack of the used fungus and its efficacy in the accelerated laboratory test.

\section{Acknowledgements}

The authors thanks to National Council for Scientific and Technological Development (CNPq), Pro-Rectory of Research, and Graduate Studies, Federal University of Pará (PROPESP /UFPA) and FAPESPA -ICAAF 001/2018 by their financial support.

\section{Referências}

Almeida NA, Mendes LM, Okino EYA, Garlet A, Mori FA, Mendes RF. (2012) Biodeterioração de produtos à base da madeira de cedro australiano (Toona ciliata M. Roem. var. australis). Cerne, Lavras, 18 (1): 17-26. 
Alves MVS, Costa AF, Espig DS, Vale AT (2006) Resistência natural de seis espécies de madeiras da região amazônica a fungos apodrecedores, em ensaios de laboratório. Ciência Florestal, Santa Maria, 16(1): 17-26.

American Society for Testing and Materials - ASTM D2017. Standard test method for accelerated laboratory test of natural decay resistance of wood. Annual Book of ASTM Standads, West Conshohocken, PA, 2005. DOI: 10,1520 / D2017-05.

Batista JF, Carneiro PD, Nascimento GO, Santos AMS (2013) Relação entre o teor de umidade e a proliferação de fungos em madeira de espécies florestais. Enciclopédia Biosfera, Centro Científico Conhecer - Goiânia, 9(17):831844.

Carvalho DE, Santini EJ, Gouveia FN, Rocha MP (2015) Resistência natural de quatro espécies florestais submetidas a ensaio com fungos apodrecedores. Floram - Floresta e Ambiente, 22(2): 271-276.

Curling SF, Murphy RJ (2002) The use of the Decay Susceptibility Index (DSI) in the evaluation of biological durability tests of wood based board materials. Holz als Roh- und Werkstoff; 60(3): 224-226. http://dx.doi.org/10.1007/ s00107-002-0284-2.

França, TSFA (2014) Caracterização tecnológica das madeiras de duas espécies de mogno africano (Khaya ivorensis A. Chev. e Khaya senegalensis (Desr.) A. Juss.). Dissertação (Mestrado em Ciências Florestais) Universidade Federal do Espírito Santo, Jerônimo Monteiro - ES.

Instituto de Pesquisas Tecnológicas do Estado de São Paulo - IPT. Informações Sobre Madeiras. Disponível em: $<$ http://www.ipt.br/consultas_online/informacoes_sobre_ madeira/busca>. Acesso em: 28/04/2016.

Marcondes E, Ribeiro MA, Stangerlin DM, Souza AP, Melo RR, Gatto DA (2013) Resistência natural da madeira de duas espécies amazônicas em ensaios de deterioração de campo. Scientia Plena, 9(6):1-9.

Modes KS, Lazarotto M, Beltrame R, Vivian MA, Santini EJ, Muniz MFB (2012) Resistência natural das madeiras de sete espécies florestais ao fungo Pycnoporus sanguineus causador da podridão-branca. Cerne, Lavras, 18(3): $407-$ 411.

Moreschi JC (2013) Biodegradação e preservação da madeira. 4. ed. Curitiba: Universidade Federal do Paraná/Departamento de Engenharia e Tecnologia Florestal, v.1, p. 1-49.

Motta JP, Oliveira JTS, Paes JB, Alves RC, Dambroz GBV (2013) Resistência natural da madeira de Tectona grandis em ensaio de laboratório. Ciência Rural, Santa Maria, 43(8): 1393-1398.

Nahuz, M. A. R.; Miranda, M. J. A. C.; Lelo, P. K. Y.; Pigozzo, R. J. B.; Yojo, T. Catálogo de madeiras brasileiras para a construção civil. São Paulo: Instituto de Pesquisas Tecnológicas do Estado de São Paulo. 2013. ISBN 978-85-09-00175-9.

Oliveira JTS, Souza LC, Lucia RMD, Souza Júnior WP (2005) Influência dos extrativos na resistência ao apodrecimento de seis espécies de madeira. Revista Árvore, Viçosa, 29(5): 819-826.

Okino EYA, Pastore TCM, Camargos JAA, Coradin VT R, Teixeira DE, Santana MAE, Fagg, CW (2015). Accelerated laboratory test of three Amazonian wood species called tauari, exposed to white- and brown-rot fungi and color response according to Cie L* A* B* System. Ciência Florestal, Santa Maria, 25(3):581-593.

Paes JB (2002) Resistência natural da madeira de Corymbia maculata (Hook.) K.D.Hill \& L.A.S. Johnson a fungos e cupins xilófagos, em condições de laboratório. Revista Árvore, 26(6): 761-767.

Paes JB, Melo RR, Lima CR (2007) Resistência natural de sete madeiras a fungos e cupins xilófagos em condições de laboratório. Cerne, Lavras, 13(2): 160-169.

Pilocelli A, Stangerlin DM, Pereira RL, Gatto DA, Calegari L, Pariz E, Susin F (2015) Resistência natural das madeiras de cumaru, cedrinho e paricá submetidas a ensaios de deterioração de campo. Ciência da Madeira, Pelotas, 6(1):1-10. DOI: $10.12953 / 2177-6830 / \mathrm{rcm}$.

Romanini A, Stangerlin DM, Pariz E, Souza AP, Gatto DA, Calegari L (2014) Durabilidade natural da madeira de quatro espécies amazônicas em ensaios de deterioração de campo. Nativa. Pesquisas Agrárias e Ambientais, Sinop, 02(01):13-17. DOI: $10.14583 / 2318-7670$

Stangerlin DM, Costa AF, Garlet A, Pastore TCM R (2013) Resistência natural da madeira de três espécies amazônicas submetidas ao ataque de fungos apodrecedores. Ciência da Madeira, Pelotas, 4(1): 15-32. DOI: 10.12953/2177-6830.

Silva FAZ, Azevedo CAV (2016). The assistat software version 7.7 and its use in the analy sis of experimental data. African Journal of Agricultural Research, 11, 3733-3740. DOI: 10.5897/AJAR2016.11522. 